Article

\title{
There Is No Such Thing as Sustainable Tourism: Re-Conceptualizing Tourism as a Tool for Sustainability
}

\author{
Gianna Moscardo $^{\dagger} * *$ and Laurie Murphy ${ }^{\dagger}$ \\ School of Business, James Cook University, Townsville QLD 4811, Australia; \\ E-Mail: laurie.murphy@jcu.edu.au
}

$\dagger$ These authors contributed equally to this work.

* Author to whom correspondence should be addressed; E-Mail: gianna.moscardo@jcu.edu.au; Tel.: +61-7-4781-4254; Fax: +61-7-4781-4019.

Received: 1 December 2013; in revised form: 19 April 2014 / Accepted: 21 April 2014 /

Published: 30 April 2014

\begin{abstract}
Increased global concern about sustainability has placed pressure on businesses to justify the value of their products and services beyond personal profit and to take responsibility for the negative impacts of their activities. Tourism is particularly susceptible to this pressure, given its generally poor track record in terms of negative social, cultural and environmental impacts, and the lack of compelling evidence of benefits for either the individual tourist or destination communities. While the management of tourism impacts and the relationship between tourism and sustainability have been paid considerable attention by tourism academics, there is little evidence of any significant change in tourism practice. This paper will argue that this lack of change reflects problems in the way tourism academics have conceptualized sustainable tourism. After reviewing these problems with sustainable tourism, this paper will offer an alternative framework for sustainable tourism that focuses on the concept of quality-of-life, recognizes the complexity of tourism within local and global systems, adheres to the principles of responsible tourism, and explicitly assesses the value of tourism as one tool, amongst many, for sustainability. One potential application of the framework will be demonstrated with a case study of tourism development on Magnetic Island in Australia.
\end{abstract}

Keywords: tourism sustainability; quality of life; sustainable tourism; tourism planning 


\section{Introduction}

A recent international media headline read "Hawaiian town of Kailua asks state to stop recommending it as a tourist destination" [1]. According to the article, the Neighborhood Board lobbied the state tourism agency to stop promoting tourism to their community reporting significant negative impacts of tourism that far outweighed any benefits. These negative impacts included inflation, increases in housing prices, loss of social networks, an influx of temporary strangers, increased crime, and tourists demonstrating undesirable behavior to local children [1]. The story seems sadly familiar, both in Hawaii, where Cohen [2] describes a 1971 media story with the headline "Please don't visit Hawaii until we can save what's left" (p. 227), and in many other destinations. While, the style of tourism may have changed over the forty years between these stories, the fundamental problem of trying to balance the competing pressures and impacts associated with tourism remains. Despite more than 30 years of academic attention and much discussion of sustainable tourism (ST), it appears that little has changed in the practice of tourism in many places. This paper will review some of the problems identified with the concept of ST. In particular it will argue that we need to very clearly distinguish between the concept of ST and the idea of tourism as one possible tool to support sustainability at multiple levels. Taking the idea of tourism as a tool for sustainability the paper will further suggest that a more explicit consideration of how tourism affects all aspects of quality of life could support more positive tourism contributions to sustainability. The paper will propose a new framework for tourism analysis and planning and demonstrate its potential application in a case study of tourism on Magnetic Island, Australia.

\section{Tourism and Sustainability: Confusion and Conflict}

In Jafari [3] proposed four tourism research and policy platforms that described different approaches to analyzing and planning tourism. The first was the Advocacy platform, referring to the presentation of tourism as an effective economic development strategy providing employment and income. The second was the Cautionary platform, which highlighted the negative impacts of tourism, arguing against tourism because of its potential as a destroyer of societies and environments. The third was the Adaptancy platform, which argued that it was possible to have the economic benefits without the social and environmental costs if alternative or adapted forms of tourism could be implemented. Jafari used the platforms as a guide for the development of tourism education and research programs arguing that each of the first three platforms was limited and that tourism academics need to take a more scientific or Knowledge Based platform [3]. Although these four platforms emerged sequentially over time, all continue to exist and it is in the interplay between the first three platforms that we can see the beginning of concerns about tourism and sustainability. Indeed Macbeth in 2005 [4] argued that tourism and sustainability could be seen as a fifth platform given the considerable attention that tourism academics have paid to this relationship since the early 1990s.

One major outcome of this attention has been the rise of the concept of ST. Several authors have provided historical reviews of this concept and its previous and current use in tourism [5-7]. What is of most relevance to this special issue and the present paper are the critiques of its formulation. Five main issues with regard to ST have been identified - it is tourism or tourist-centric, it is focused 
on the destination space and ignores the larger global system that tourism is a part of, it highlights environmental concerns and often ignores other dimensions of sustainability, it is usually driven by academics and institutions that present sustainability as an objective, scientific concept best achieved by the development and enforcement of rules and guidelines for specific practice, and it is not integrated into other activities [5-10].

Moscardo [11] repeated Getz's [12] review of tourism planning models and concluded that very little had changed in thirty years in the way tourism planning processes are conceptualized and used in academic and government documents. Both reviews identified problems that included:

- A narrow focus on specific projects, rather than considerations of tourism as a whole;

- Limited attention given to tourism impacts;

- A focus on economic factors with occasional limited acknowledgement of environmental issues;

- A failure to consider how tourism would interact with, and effect other activities at a destination;

- The naïve adoption of business strategic planning as the dominant framework for tourism planning, and, as a consequence;

- The placement of market or tourist needs and expectations as the core drivers of tourism planning, giving destination residents a very limited role, if any.

This placement of tourist or market needs as the core driver of the process, and the often unstated and unchallenged assumption that a viable and profitable tourism industry is the end goal of tourism planning has unfortunately also been adopted in most applications of ST [7,10,13,14]. Guidelines for ST practice assume that some form of tourism practice is sustainable and rarely, if ever, is "no tourism" considered as a serious option.

ST is typically translated into sets of guidelines and rules for practice that focus almost exclusively on immediate, local, environmental impacts and are driven by academics and organizations that adhere to a view of sustainability as an objective concept supported by science $[4-7,9,10,13,14]$. While it is important to address immediate local environmental impacts of tourism, a failure to consider the wider, cumulative, long-term and other impacts of tourism means that it may be possible to label an activity as ST even if it fails to address the bulk of the issues identified in the wider sustainability literature. A critical examination of the application of ST to the Great Barrier Reef provides an example of this problem. While climate change is identified as a major threat to this natural environment, a distinguishing characteristic of many tourists to the destination is that they have to take long haul flights or drive considerable distances to get the destination, thus contributing directly to the problem of climate change. Discussions of ST in this destination do not, however, include consideration of the carbon emissions associated with travel to the destination [15]. This problem is not just limited to spatial and temporal limitations. According to Macbeth [4] ST is often locked into a conservation ethic and so emphasizes environmental issues adopting an ecological approach that "is susceptible to social indifference" (p. 968). These gaps in ST are partly the result of the fourth problem; the dominance of external experts in the development of ST rules, guidelines and standards which assume a shared objective scientific view of sustainability. This framing of ST further disempowers other stakeholders, especially local residents [7-10], ignores the value-laden, subjective, cultural nature of sustainability, and thus fails to address the justice issues that are critical to understanding the origins of unsustainability $[4,6,7]$. 
Jafari provided an update to his four original platforms and argued for a fifth or Public platform in which tourism would look outwards towards other activities and other sources of knowledge [15]. In this argument he described tourism as "self-endorsing, inward-looking [and] narcissistic" (p. 2). While Jafari was referring to tourism research and practice as a whole, ST is particularly problematic in this regard with no consideration given to the extent to which tourism in any place or at any level effects other socio-economic development strategies. Tourism is assumed to be not just an end in itself, but a solitary activity that neither impacts on, nor is impacted by, other sectors. This failure to consider integration with other development actions also limits the extent which tourism can be seen as sustainable $[12,16]$.

Suggestions for addressing these issues fall into four categories. The first and most common is a more explicit consideration of ethical approaches to tourism and issues of social justice $[4,7,17,18]$. These discussions direct tourism researchers to consider more carefully their own personal ethics and the impacts of their actions on others [4]. According to Jamal, Camargo and Wilson [7], in their contribution to this special issue, the use of ethics and justice to guide tourism towards sustainability is better served by the idea of responsible tourism rather than ST. Responsible tourism is seen as tourism that:

- Involves the host community in tourism governance;

- Actively seeks to minimize all negative impacts;

- Generates economic benefits for locals, contributes to cultural and natural heritage, and enhances the overall well-being of the host community;

- Is accessible to all; and

- Provides tourists with meaningful experiences that give them a better understanding of cultural, social and environmental issues relevant to the places they visit as well as the larger, global setting [19].

Responsible tourism is consistent with the second category of suggested future directions, which is the explicit recognition and assessment of tourism in terms of well-being or quality of life (QoL). These two terms, well-being and QoL, are often used interchangeably. The OECD [20], for example, defines QoL as "the notion of human welfare (wellbeing) measured by social indicators rather than by 'quantitative' measures of income and production" (p. 1). QoL refers to the idea that a good and satisfying life depends on meeting key basic needs [21,22]. These needs are physiological, including food, water, good health, and security, opportunities for education, productive activity and involvement in relevant decisions, belongingness, and self-esteem. These needs are, in turn, met through access to a set of capitals described in Table 1 [21-23]. Well-being is often seen as the broader term and so for the purposes of this paper the term QoL will be used for the individual level of analysis, while the term community well-being $(\mathrm{CW})$ will be used at the social level of analysis. This differentiation is provided to make subsequent discussion easier for the reader to follow.

Definitions of sustainability increasingly use the idea of well-being or QoL and the importance of multiple forms of capital as central elements, suggesting that sustainability is about increasing all forms of capital, not just financial or built capital, recognizing that natural capital is especially important because it cannot be substituted with other forms [24-26]. The importance of multiple forms of capitals and QoL has been recognized in recent tourism and sustainability discussions [9,21,27-30] with a growing number of researchers arguing for the use of QoL as way to assess the sustainability of tourism $[9,21,27,28,30]$. 
Table 1. Main Types of Capital that Support QoL. Source: [24] (p. 534).

\begin{tabular}{ll}
\hline Type of Capital & Description \\
\hline Financial & Income, savings, and access to funding for investment. \\
\hline Natural & $\begin{array}{l}\text { Natural ecosystems and the assets, services and resources that they provide includes } \\
\text { landscape, environmental systems, green spaces and conservation areas }\end{array}$ \\
\hline Built & $\begin{array}{l}\text { Physical facilities and infrastructure that communities have available for use including } \\
\text { buildings, transport systems, public spaces, technological systems and distribution } \\
\text { systems for water, waste and energy. }\end{array}$ \\
\hline Social & $\begin{array}{l}\text { Features of social networks such as trust, reciprocity and cooperation and social } \\
\text { institutions and associations }\end{array}$ \\
\hline Cultural & $\begin{array}{l}\text { Values and symbols shared by human groups and manifested in things such ritual and } \\
\text { social activities, arts and crafts, spiritual practices, languages and celebrations }\end{array}$ \\
\hline Human & The capabilities, skills, knowledge and health of the people who make up a community \\
\hline Political & Ability to access political decision making processes and influence governance \\
\hline
\end{tabular}

Moscardo, for example, proposes a QoL framework for considering tourism impacts that suggests that different types of tourist activity can be assessed according to their positive and negative impacts on each of the capitals listed in Table 1 [21]. Of importance to the present discussion is that this framework also argues that the assessment needs to be done at several levels including the individual tourist, stakeholders in the regions that tourists leave, stakeholders in transit regions, stakeholders in destination regions, and the people who work in tourism [21]. According to this framework ST has to result in net benefits across all the types of capital for the individual tourists, the generating, transit and destination communities, the people who work in tourism and more globally. This recognition that tourism exists simultaneously at multiple levels is the third theme in suggested new directions for ST [7]. The argument here is that assessment of tourism impacts must not be limited to the destination level. The growing literature on the contributions of tourism to climate change [31] is a clear example of how tourism impacts extend beyond the destination. In a similar fashion it could be argued that tourism that exploits the global North-South divide by offering experiences in the global South based on the lower costs resulting from lower standards of living is also not sustainable in a global sense [7,32].

Finally, there are calls to devise new approaches to tourism planning. Moscardo's 2011 [11] review of tourism planning models and approaches identified a consistent set of patterns in terms of the number and sequence of steps or phases in the planning process, the identification and engagement of key stakeholders and the underlying assumptions. The main planning steps in their most common sequence are presented in Figure 1. Traditional formal approaches to tourism planning are typically focused on the destination level and generated by groups external to the destination community such as regional or national government agencies or development organizations. These external agents then usually appoint a planning group of some sort who take responsibility for the plan and set the objectives or goals. Within this traditional process it is always assumed that some form of tourism is desirable and the goal of the plan is to ensure that tourism as a commercial activity is financially successful for tourism businesses, regardless of who owns those businesses. The second common step is to analyze the situation combining both an assessment of the destination and its residents in terms of the assets and resources they can provide to support a viable tourism sector and an examination of potential tourist markets. This information is then used to develop plans or strategies and following 
that to move to implementation and monitoring. It is typically presented and considered as a linear process. Where opportunities for community or public engagement or participation are provided, and that is not always the case, they are most often included after the development of the plans/strategies and focused almost exclusively on generating public support for the decisions already made. In some cases there is an opportunity for some input from the destination community into the development of the plans themselves. Other critical reviews of tourism planning processes and development policies by Hall [33] and Ruhanen [34] provide consistent conclusions to those described by Moscardo [8,11]. These critiques further argue that, despite the addition of sustainable tourism as a goal in many plans and increased attention paid to environmental impacts of tourism, this traditional approach to tourism planning remains largely unchanged and thus is unlikely to improve the sustainability of tourism.

Figure 1. The traditional tourism planning process.

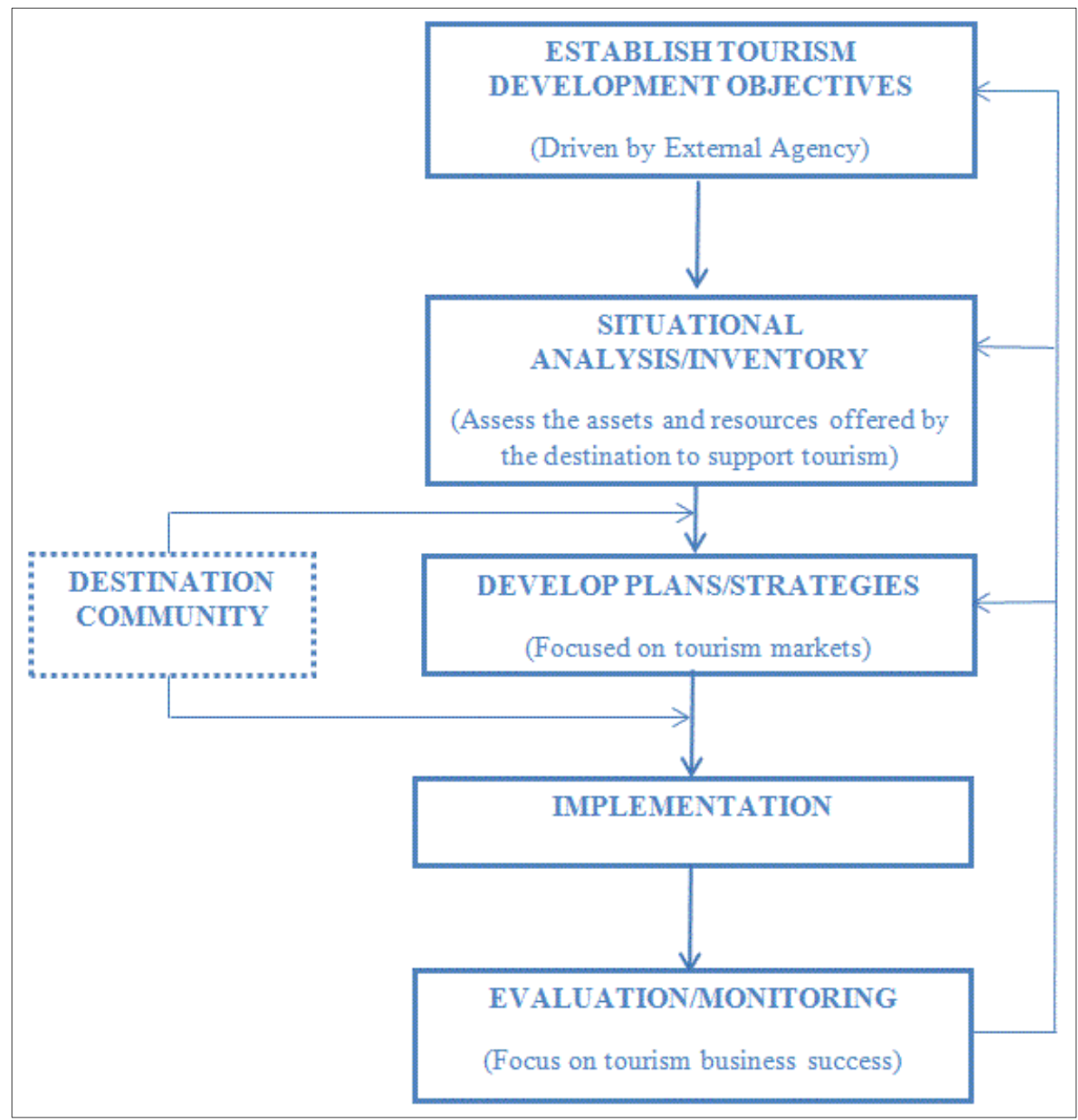

The analysis thus far suggests that new approaches to tourism planning and development are needed. These new approaches should take into account the need for multiple levels of analysis and address QoL beyond simple economic and environmental dimensions [4,11]. New approaches to tourism planning would also need to respond to the challenges of effective governance and public participation, giving a stronger voice to destination residents and involving a wider range of stakeholders than those directly involved in tourism [5,11]. If tourism is to contribute to sustainability at all levels then arguably tourism planning should also involve some form of sustainability evaluation of tourism 
development proposals before they are implemented. Despite a growing literature on sustainability assessment of tourism, the proposed systems are designed for existing tourism activities and the outcomes of tourism developments [35,36]. Such a pre-implementation assessment would more directly consider tourism as one possible tool for achieving sustainability and examine its value as a means to an end, rather than an end itself. Thus proposed tourism projects would be assessed according to the resources that they would provide for use by residents, the assets that would be enhanced and the opportunities that would be provided for other commercial, social and cultural activities [8]. Rather than asking what resources are available in the destination for tourism, this type of sustainability assessment would ask what resources tourism would bring to the region and how tourists could be used to meet the needs and aspirations of destination residents and non-tourism businesses.

In summary the problems identified with current conceptualizations of ST and traditional tourism planning approaches stem from three unquestioned assumptions:

- That tourism is an end in itself and so tourists are the key stakeholders of interest;

- That tourism is primarily a source of financial capital which is assumed can be exchanged for other capitals, and

- That negative tourism impacts are mostly confined to the physical environment of the specific destination.

If tourism is to move towards a greater contribution to sustainability there is a need to reconsider the relationships between tourism and sustainability and to find, apply and test new planning approaches. The present paper seeks to address these needs by outlining a re-conceptualization of tourism development and sustainability that replaces these common assumptions and explicitly casts tourism as a means to improving well-being, rather than an end in itself, that the key stakeholders are those that have to live with consequences of tourism, and that tourism impacts extend beyond the destination in multiple dimensions and across multiple levels of analysis. As such the paper is not filling a research gap but rather seeks to address these conceptual issues in the dominant planning paradigms for tourism. To address this need it describes a possible alternative tourism planning framework and then uses a single case study to critically analyze how this new framework might work in practice.

\section{Re-Conceptualizing Tourism as a Tool for Sustainability}

This section outlines an alternative approach to conceptualizing the relationship between tourism and sustainability using a Quality of Life (QoL) approach. This QoL approach is used to build an alternative tourism planning framework for destinations that seeks to address the issues identified in the previous review sections. Figure 2 provides an overview of a QoL approach for assessing the sustainability of tourism in general. This approach proposes that in order to be considered sustainable, the tourism development or business must:

- Demonstrate net positive contributions to each of the forms of capital listed on the right hand side of the diagram, paying particular attention to natural capital;

- Be applied at all levels; and

- Consider all the issues listed on the left hand side of diagram. 
Figure 2. A quality of life (QoL) approach for assessing tourism sustainability.

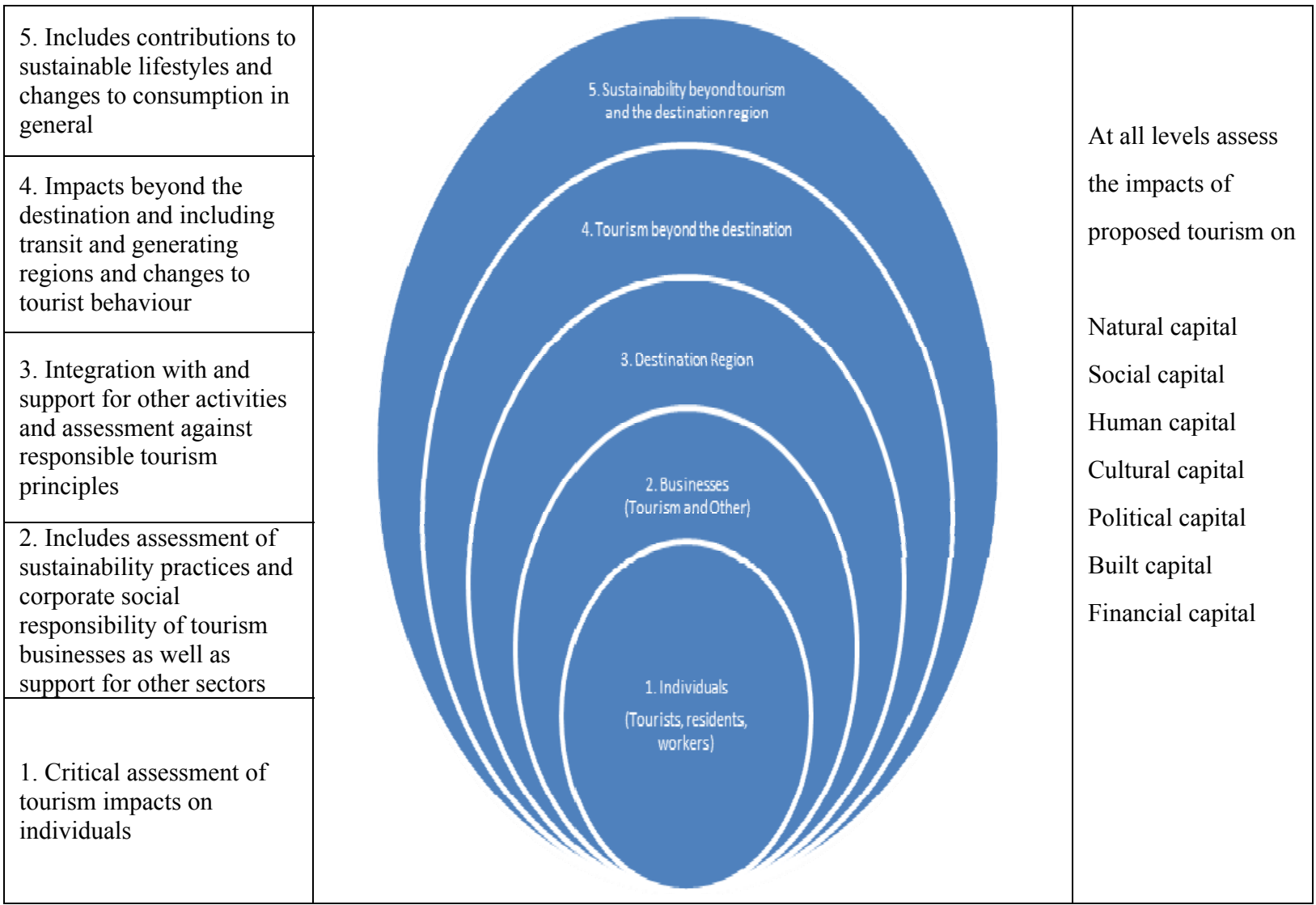

For example, a proposal to develop farmstays in a rural region would have to demonstrate the benefits of the activity for all the forms of capital for the host farmers and their families, other residents and business in the destination region, and the tourists themselves. These analyses would include a consideration of any opportunity costs associated with the proposal and examine how the activity would contribute to other activities. The proposal would have to detail the risks and management responses associated with negative impacts on all the forms of capital for all the levels. At the level of the business the model is similar to the concept of sustainable livelihoods [37]. The approach goes beyond this to include other businesses outside of tourism, the working conditions of tourism staff, the benefits and costs for the tourists, and the impacts of the tourism beyond the destination including such things as the carbon emissions for the associated travel to the region and impacts on transit regions. Finally the assessment of this proposed tourism activity would have to consider how it influences sustainability beyond tourism. It could be argued, for example, that the presence of tourists might support shifts towards more sustainable agricultural practice on the farms and that exposure to the daily lives of farmers, supported by appropriate interpretation, might encourage tourists to consider and change their subsequent food purchases.

This example shows how the QoL approach could be used to assess tourism proposals and through that assessment how proposals could be revised to improve contributions to sustainability. The approach can be used to guide tourism planning at multiple levels. At the individual level with a focus on tourists, for example, it could be used to support more detailed and effective guidelines for being a responsible tourist. At the level of sustainability beyond tourism it directs attention to the potential role 
of tourism as a form of social marketing to support sustainability action [38]. At the destination level it provides a way to compare different types or forms of tourism and to compare tourism to other socio-economic development options.

The QoL approach to assessing the sustainability of tourism outlined in Figure 2 can also be used to support alternative approaches to tourism planning. Although tourism planning can be conducted at a number of levels, regional or destination tourism planning remains the dominant point at which tourism proposals and projects are evaluated and the framework can be used to suggest alterations to traditional tourism planning processes at this level. Figure 3 provides a basic outline of an alternative framework for destination tourism planning based on the QoL approach. As this particular framework is applied to the destination it is focused on Community Wellbeing $(\mathrm{CW})$.

The framework places the destination community at the centre of tourism planning activity, strengthening community engagement across the whole process. A common conclusion in the literature on public participation in development planning is the need to move from simply informing residents about the plans or seeking their input into plans established by others, to empowering residents to control the planning and development process [39]. Thus a critical element of tourism planning has to be finding ways to build community capacity to effectively make decisions about tourism. Moscardo [21] addresses in more detail the dimensions of tourism governance needed to achieve this, highlighting the importance of developing effective leaders, networks and partnerships and, in particular, educating destination residents and stakeholders about tourism, especially its impacts [40]. The development of effective governance for tourism planning is not likely to be easy in practice and will vary according to the nature of the destination community and the larger political, social, and cultural context. Marzuki and Hay [39] offer a system that could be adapted to a wide range of situations to assist in the development of such governance structures.

Reviews of community development beyond tourism also challenge the role of external consultants arguing for a shift away from consultant experts to facilitators and coordinators with longer term relationships with the communities in question [41]. Feighery makes a similar argument in his discussion of the ethics of academics acting as tourism development consultants, outlining in detail the conflicts of interest that often accompany the work of tourism academics [42]. While the framework described in Figure 3 does not include a specific element it is recognized that external agents will inevitably be involved in tourism planning. The framework suggests that such external agents should be assessed in terms of the resources they offer to the tourism planning process.

As destination communities develop their capacity for tourism governance, the CW framework re-conceptualizes tourism as a tool for destination stakeholders and sets the main goal of tourism planning as supporting improvements in wellbeing for destination communities and achieving improvements to sustainability at a number of levels. Instead of assessing the resources available for tourism, this approach argues for an assessment of the stock of the various capitals available to destination residents, and the major sustainability issues that face the destination. The aim being to determine the destination needs rather than tourist attraction potential. Once these needs are identified, the process moves to the generation of tourism options that might address these needs. This requires the use of futures scenario building techniques that are not often used in tourism planning [43].

Once the range of possible tourism scenarios is identified, the next stage in the planning process assesses each scenario according to the resources it offers to the destination, its likely impacts, both 
positive and negative, on the different forms of capital that make up $\mathrm{CW}$, its business viability and its sustainability with regard to the other four levels of the QoL assessment approach. The viability assessment is especially important as many alternative approaches to tourism such as community based tourism often fail to consider the market support for, and competitiveness of, tourism projects [44]. The sustainability assessment at this stage should also look at issues beyond the destination including costs and benefits for the tourists, the nature of the working environment for tourism staff, impacts on transit and generating regions and contributions to sustainability beyond tourism. The last two stages, implementation and monitoring are similar to those put forward for traditional tourism planning approaches.

Figure 3. A community well-being approach to destination tourism planning.

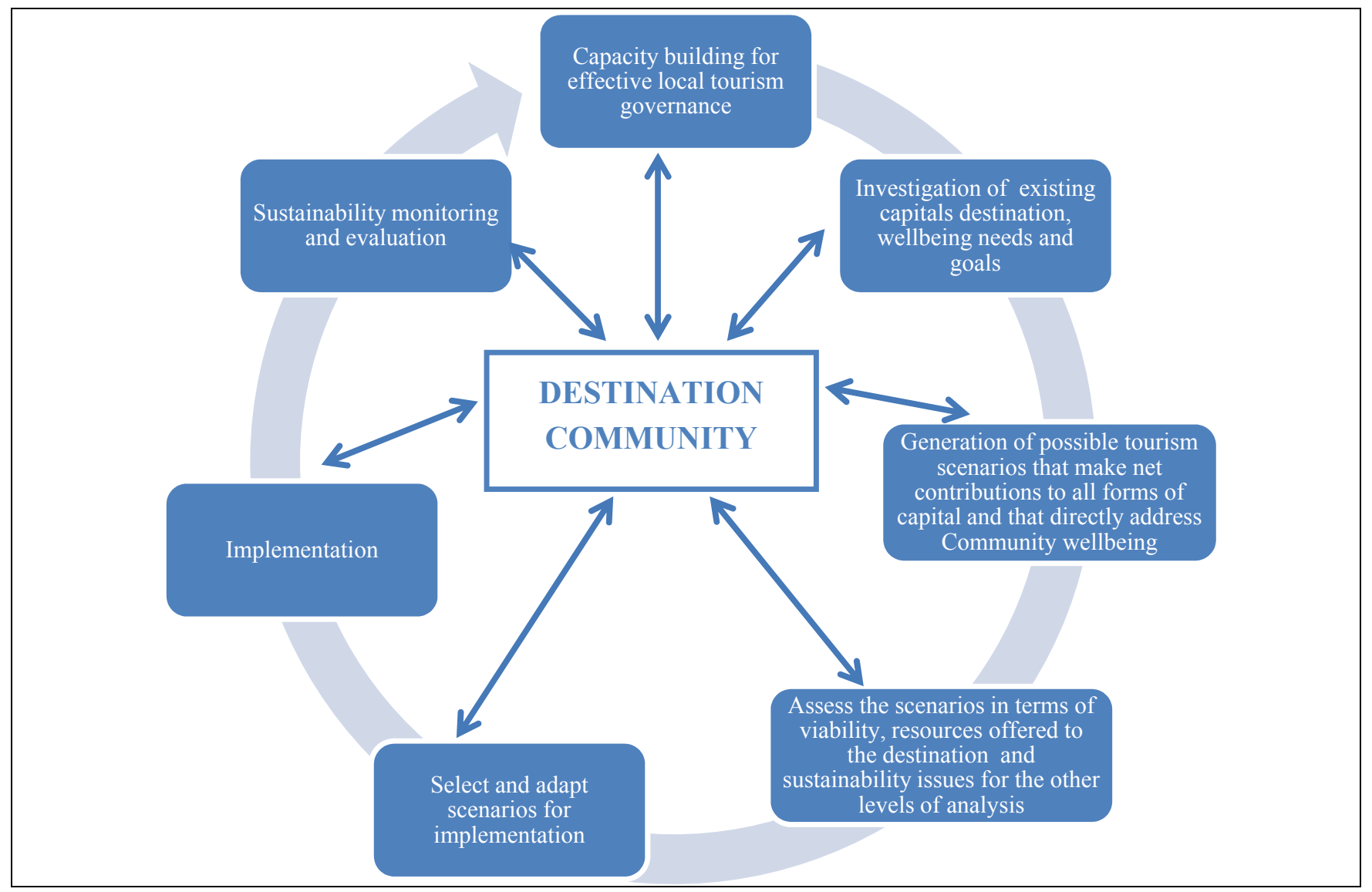

\section{Re-Conceptualizing Tourism as a Tool for Sustainability in Practice: An Application Case Study}

This section will describe the potential application of these proposed alternative approaches to tourism and sustainability using a case study of tourism development and planning on Magnetic Island in Australia. This location was chosen as a case study for three main reasons. Firstly, the history of tourism development in this location is very similar to that described in many other places and these similarities will be noted where relevant in the case study description. This history of tourism development also highlights many of the issues raised in the previous sections. Secondly, the community in this location has been involved in a number of sustainability initiatives, has begun to question the role of tourism in supporting their broader sustainability aspirations, and has been 
explicitly seeking alternative styles of tourism and approaches to tourism development. Thirdly, Magnetic Island is located close to the university where the authors are employed making it easier to be involved with the whole process more intensively and extensively and offering an opportunity to be engaged in tourism research and outreach that made a more direct contribution to sustainability in practice. The aim of using a case study is to demonstrate how the proposed planning framework might be applied in practice. The case study is a demonstration or example of application, not a specific research study, so the focus of the case study description is on the overall sequence of events and actions with some key results from different phases to explain the process overall.

Magnetic Island (MI), with an area of $52 \mathrm{~km}^{2}$ (20 square miles) is located eight kilometers (5 miles) off the northeastern coastline of Australia adjacent to the regional city of Townsville [45]. More than half of MI (65\%) is National Park and much of the island is inaccessible to vehicles. It is a suburb of Townsville with a population of approximately 2300 residents, many of whom commute daily by ferry to the mainland for work and to attend school [46]. The island is home to a wide range of wildlife, has a number of historical sites related to both traditional use by local Indigenous groups and European settlement, especially in relation to World War Two forts and observation posts [45]. MI is also part of the Great Barrier Reef World Heritage Area and Marine Park and its beaches and fringing coral reefs attract local recreationists and tourists.

\subsection{A Brief history of Tourism Development on Magnetic Island}

MI has been a popular recreational site for Europeans since settlement in the area in the 1800s with Townsville residents sailing there for day trips and picnics [47]. From the late 1890s until the early 1980 s there was a steady increase in both residential growth and the development of small scale tourist accommodation and facilities [48]. In 1984 the announcement of a major tourist development proposal triggered twenty years of conflict over the nature of tourism development on MI. This development, which is most commonly referred to as the Nelly Bay Harbour project [49], has dominated considerations of tourism on MI to the present time. The original proposal was for an extensive complex including accommodation for more than 1300 tourists, nearly 100 home sites, an all-weather ferry terminal, a marina, tavern, sports complex, commercial center and new beach. The proposal involved significant alterations to the existing landscape including the removal of a headland and major reclamation and dredging [49]. The announcement marked the start of an extended period of permit and approval applications, impact assessments, public objections and court cases, accusations of political bribery, multiple changes in ownership and the financial collapse of several of the business stakeholders and ultimately the development consortium itself in 1998 [49-51]. In 2003 a much smaller development consisting of a ferry terminal, one resort and a marina was completed [49]. The development site continues to create problems with significant areas of construction unfinished and in a decaying state, and ongoing environmental issues [52]. Most importantly for the present discussion is the legacy of conflict and mistrust amongst residents [49-51,53,54]. According to Moyle, Croy and Weiler [54], while there is recognition of the economic and infrastructure benefits of tourism, many residents continue to be opposed to any form of tourism and this can be expressed in hostility towards tourists. Many residents also report feeling a sense of no control over development decisions and disengagement from community life. 
Arguably the development has also had negative impacts on tourism to the island, with widespread media coverage of the environmental damage, losses to tourism businesses who invested in the destination based on the development promises, the presence of the unfinished construction at the main arrival point for visitors, and confusion over the style of experience on offer. This sequence of events and patterns of impacts are consistent with those reported in many other locations. The reader is directed to Asher, Roe and Goodwin [55], Blackstock [56], Dredge [57], Holladay and Powell [58], Lee, Riley and Hamilton [59], Moscardo [21], and Park Lee, Choi and Yoon [60] for examples of similar histories for a range of different locations and for different types of tourism.

The wider region attracts nearly one million tourists annually, made up of approximately $75 \%$ domestic and 25\% international tourists, and around one quarter of these tourists visit MI [61]. It is difficult to estimate the number of recreational visits by regional residents, but generally there is a perception that all visitor numbers could be improved and that MI tourism businesses have faced significant challenges in recent years due to the global financial crisis, a strong Australian dollar, and damage from cyclones.

\subsection{Recent Tourism Planning Exercises}

In this setting formal tourism plans are made by the state government using traditional tourism planning approaches which include consultations with "government agencies, tourism industry, tourism stakeholders, developers and investors" [62] (p. 3). Two planning documents were relevant at the time of the start of the MI project, the Tourism Opportunity Plan (TOP) [63] and the Destination Management Plan (DMP) 2007-2010 [62]. The main goal of the Destination Management Plan was to increase visitor numbers, length of stay and visitor expenditure in the wider region. Secondary aims included improving overall marketing impact and promoting sustainable management and development of tourism. The bulk of the plan focusses on improved marketing to existing groups of tourists and capitalizing on the traditional assets of a tropical climate, beaches and proximity to natural environments. The aim of sustainable management is addressed with strategies aimed at enhancing the ongoing viability of tourism with statements such as "maintaining and expanding low-cost air access" [62] (p. 11). Consideration of sustainability beyond this is restricted to ensuring "ongoing protection of the destination's natural attractions" and "distribution of up-to-date information on the effects of global warming" [62] (p. 11). Discussion of resident and non-tourism stakeholder engagement is covered in the following two statements:

- Continue to promote the value of tourism and economic benefits to the community (including jobs, career paths) to encourage support of holiday, visiting friends and relatives and business visitors;

- Maximize community support for tourism by increasing awareness of how the community's interaction with visitors is central to the quality of the visitor experience [62] (p. 12).

This plan is supplemented by the TOP which lists and describes a set of tourism projects and infrastructure development required to achieve the goals set in the DMP. In this plan MI is identified as a Sustainable Destination reflecting its location on the Great Barrier Reef and the commitment of the residents to a number of sustainability initiatives [63]. These plans and the 
overall planning approach are very much like those identified and critiqued in reviews of tourism planning approaches [33,34].

\subsection{Magnetic Island Sustainability Aspirations}

In recent years MI residents and businesses have pursued a number of sustainability initiatives. The most notable project has been involvement in the Solar City program [64]. As part of this program many residents and businesses installed solar panels to generate electricity with one of the highest residential uptakes of solar panels in the state [65]. The Solar City program also involved household energy audits, the establishment of a small education center on energy efficient suburban living, and has won an Australian Sustainable Cities Award [66]. The program has also postponed the need to install an additional sub-marine power cable from the mainland [67]. Water is piped to MI from the mainland and the local government, with the support of the residents, has invested in a water recycling plant and a number of programs to limit both the use of water and disposal of waste water into the ocean [68]. Other initiatives that have been discussed for the suburb include a ban on plastic bags and bottles, a move to electric powered public transport vehicles and the desire to become a carbon neutral suburb. These sustainability initiatives have been supported by MI tourism businesses. In 2010 a community forum was held to seek widespread input on how to build more sustainable tourism on the island. The key conclusion from these discussions was the need to manage tourism to be consistent with community sustainability aspirations and to develop new forms of tourism that could actively support these aspirations. Nineteen of the local tourism businesses have signed up to a ST program requiring them to audit their energy, water and carbon use and waste generation and commit to programs to improve performance in all these areas [69].

\subsection{Assessing Tourism as a Tool to Support Sustainable Lifestyles}

In 2010 the authors were involved in discussions with different stakeholder groups about the challenges of tourism and sustainability on MI as part of conducting research into tourism in the wider region. A change in the ownership of the passenger ferry that provides the main access to MI also prompted a series of discussions around how to revitalize tourism to MI. In 2011 the state government called for proposals to examine in more detail the feasibility of the projects described in the TOP. This represented an opportunity to work within the existing government planning system to attempt to develop tourism strategies that would be more sustainable and make a positive contribution to $\mathrm{CW}$ on MI. The authors were able to organize and coordinate a group consisting of representatives from local government, the regional tourism organization, MI tourism businesses, and MI community organizations to provide matching funding, successfully apply for the grant and guide the project. The funding opportunity was identified by several stakeholders and the decision to pursue it taken at group meetings. The actual proposal was directly funded by the ferry company, Sealink, the local city council and the state government development agency and indirectly supported by the university, the regional tourism promotion and marketing organization, and several MI business and community groups. Thus the main impetus for the project came from within the MI community and tourism businesses.

The proposed project was a planning and action research exercise to determine what, if any, type of tourism or tourist would support the sustainability aspirations and overall well-being of the residents 
and business operators of MI. The project was seen as a trial of the both framework and the planning approach outlined in Figure 3 with the starting point being local stakeholder needs and aspirations, with a focus on developing community capacity for tourism governance and explicitly assessing tourism as a tool for sustainability. The project was guided by the following questions.

- What are the key dimensions of QoL for MI residents?

- What sustainability initiatives are most important to MI residents and business operators?

- What kinds of tourism development could support the sustainability aspirations of the MI residents and businesses?

- What level of support is there amongst current tourists for these sustainability initiatives?

- What are the characteristics of tourist markets that are most supportive of these sustainability initiatives?

The authors acted as facilitators for the project, organizing and coordinating meetings and stakeholder inputs and liaising between different agencies and groups. They also acted as a resource providing examples from other locations and conducting research required by the stakeholders. The project involved continuous input from representatives of the MI community groups and the relevant government agencies at all stages. It began with the lists of community sustainability aspirations already outlined and developed through a range of community engagement activities and a series of meetings to determine required research and to develop sustainable tourism scenarios for assessment. Then the authors coordinated a survey of tourist and regional residents to assess the viability of these scenarios and general support for MI sustainability initiatives. After the completion of the survey the authors facilitated public meetings to revisit and confirm community well-being needs and to gather community perspectives on the different sustainable tourism scenarios.

\subsubsection{Resident and Business Consultation Outcomes}

In keeping with the CW destination planning framework the project was focused on the needs and aspirations of MI residents and involved MI stakeholders in all aspects of the project with regular group and individual meetings throughout the project. In the early stages the focus was on clarifying community aspirations for sustainability and developing specific tourism scenarios that might support these aspirations. In the later stages there were open public meetings that used futures visioning exercises to explore the key dimensions of MI community wellbeing, sought input into decisions about the sustainability initiatives and the tourism development options, and presented visitor research results. Two key themes emerged from the discussions about the important features that contribute to $\mathrm{CW}$ - the sense of community and that the suburb was embedded in the natural environment. The first theme is best summarized by one of the public meeting attendees who stated that "it is a small, friendly community with a village like atmosphere". The second theme can be summarized with another quote, "the opportunity to live in harmony with the environment". When asked about things that were needed to improve community wellbeing on MI, four key themes were identified:

- Improvements to public transport;

- A need to maintain or enhance public services such as education and health which can be difficult with a smaller population in a less accessible location; 
- Support to maintain and expand the sustainability activities and programs; and

- A desire to find ways to use tourism as a support for the sustainability activities in particular, and MI wellbeing in general.

The most important sustainability initiatives were the Solar City program, a desire to be a carbon neutral suburb, supporting better management of the National Park, moving to electric powered public transport, encouraging more tourism businesses to adopt specific sustainability initiatives, and an interest in education for visitors about both the natural environment and the sustainable lifestyles. Other programs suggested but given lower priority included eliminating plastic packaging and bottles and water conservation. Consultation with the various stakeholders identified four tourism scenarios that were both consistent with MI sustainability aspirations and responsible tourism principles:

- Electric bicycle touring package;

- Environmentally friendly camping options;

- Guided Indigenous tours; and

- Activities supporting an art/cultural precinct.

\subsubsection{Tourist and Mainland Resident Survey Outcomes}

In order to analyse the perspectives of both current and potential tourists as well as mainland residents who see MI as an important recreational setting, a survey was conducted in a variety of locations including on the ferry between MI and the mainland, at various sites on the island, at major tourist attractions and transport nodes on the adjacent mainland, and at major mainland resident recreation sites, with an online option also available through various regional web links. The survey was conducted over a three week period covering local school holidays, weekends and weekdays and the major tourist season. The survey was completed by 884 respondents with just over half (51\%) surveyed at MI or on the MI ferry. The sample was relatively evenly split between regional residents (49\%) and tourists from outside the region (51\%) and included both respondents who had visited MI recently (78\%) and those who had either never visited or had not been in the previous 12 month period $(22 \%)$. The sample had a mean age of 36 years $(\mathrm{SD}=14.5)$ and consisted of $36 \%$ males and $64 \%$ females.

The questionnaire was developed in consultation with key stakeholders and included questions to profile the respondents on key socio-demographic features, to describe their travel experiences on Magnetic Island, and to examine their evaluations of, and responses to, the proposed sustainability initiatives. Initial analyses to determine what, if any, significant differences existed between regional residents and tourists from outside the region found very few differences. There were some differences in travel experiences with MI including regional residents having a greater likelihood of having been to MI, higher use of the car ferry to access the island and then higher use of their own car for transport on the island, a higher use of holiday houses for accommodation, and lower use of tourism information sources. Aside from these there were no differences in their responses to the sustainability initiatives or in their patterns of motivation, with the exception of seeking a luxury experience which was slightly more important for regional residents than tourists. As there were no significant differences for the variables of primary interest, these two groups were combined for all the analyses reported here. 
Table 2 provides a summary of the total sample responses to the questions asking about the sustainability initiatives identified by the stakeholder group. Overall the majority of respondents were supportive of the sustainability initiatives, especially the development of more responsible tourism options, a shift to electric-powered public transport and the introduction of a National Park Fee. The lower level of support for the Solar City Initiative possibly reflected low levels of awareness, with 58\% reporting that they were not aware of the program. It is worth noting that the three most popular options were those that most closely related to managing tourism's environmental impacts.

Table 2. Summary of visitor support for magnetic island (MI) sustainability initiatives.

\begin{tabular}{lccc}
\hline Sustainability Initiative & $\begin{array}{c}\text { Negative } \\
\text { Response }\end{array}$ & Neutral & $\begin{array}{c}\text { Positive } \\
\text { Response }\end{array}$ \\
\hline The Solar City initiative was/would be important in my decision to visit MI & $38 \%$ & $31 \%$ & $32 \%$ \\
\hline $\begin{array}{l}\text { The tourism operator sustainability initiatives make MI a more } \\
\text { interesting place to visit }\end{array}$ & $21 \%$ & $36 \%$ & $44 \%$ \\
\hline $\begin{array}{l}\text { I am interested to learn more about these tourism operator sustainability } \\
\text { initiatives }\end{array}$ & $28 \%$ & $35 \%$ & $37 \%$ \\
\hline $\begin{array}{l}\text { It is important that these tourism operator sustainability initiatives are } \\
\text { further developed }\end{array}$ & $10 \%$ & $24 \%$ & $66 \%$ \\
\hline $\begin{array}{l}\text { MI would be more appealing if all buses and rental cars were powered } \\
\text { by electricity }\end{array}$ & $17 \%$ & $30 \%$ & $53 \%$ \\
\hline $\begin{array}{l}\text { I would be willing to pay a \$5 National Park entry fee to visit MI if the } \\
\text { income was invested back into improving park infrastructure and facilities }\end{array}$ & $25 \%$ & $22 \%$ & $53 \%$ \\
\hline MI would be a more appealing place to visit if it was fully carbon neutral & $22 \%$ & $35 \%$ & $44 \%$ \\
\hline
\end{tabular}

Figures are the percentage of respondents giving a 1 or 2 rating (Negative), a 3 rating (Neutral) or a 4-5 rating (positive), all scales were 5 points from 1 not at all to 5 very.

Table 3 provides a summary of responses to the four tourism scenarios. The two most appealing products were the Guided Indigenous Cultural Tours and the Self-guided Electric Bike Tours, although a substantial percentage of respondents found the other two products also appealing. In all cases at least one-fifth of the sample reported that they were willing and/or able to pay the suggested amount for the product. Taken together with the results presented in Table 2, it can be argued that there is sufficient support from both current tourists and regional residents for the MI sustainability proposals to be developed further. 
Table 3. Summary of visitor responses to proposed responsible tourism products.

\begin{tabular}{|c|c|c|c|c|}
\hline Product Description & $\begin{array}{l}\text { Overall } \\
\text { Appeal }\end{array}$ & $\begin{array}{l}\text { Make MI } \\
\text { more } \\
\text { attractive } \\
\text { to visit }\end{array}$ & $\begin{array}{l}\text { Encourage } \\
\text { a longer } \\
\text { stay }\end{array}$ & $\begin{array}{l}\text { Willingness/ } \\
\text { ability to } \\
\text { Pay }\end{array}$ \\
\hline \multicolumn{5}{|l|}{ Environmentally Friendly Camping } \\
\hline $\begin{array}{l}\text { A solar powered campground set in natural surroundings } \\
\text { providing either a deluxe ensuite eco-tent accommodation } \\
\text { at approximately } \$ 130-\$ 170 \text { per night or self-catering tent } \\
\text { sites for } \$ 20-\$ 30 \text { per night with composting toilets, BBQ } \\
\text { facilities; and hot shower facilities }\end{array}$ & $29 \%$ & $21 \%$ & $17 \%$ & $\begin{array}{c}\text { Self-catering } \\
22 \%\end{array}$ \\
\hline \multicolumn{5}{|l|}{ Guided Indigenous Cultural Tours } \\
\hline $\begin{array}{l}\text { A guided } 1.5 \text { hour cultural tour with a local indigenous } \\
\text { guide which costs } \$ 25 \text { for adults, } \$ 15 \text { for children and } \\
\text { provides the opportunity to learn about the indigenous } \\
\text { history and culture of the island, the natural environment of } \\
\text { the island from an indigenous perspective, and walk to sites } \\
\text { of local aboriginal significance }\end{array}$ & $48 \%$ & $42 \%$ & $32 \%$ & $24 \%$ \\
\hline \multicolumn{5}{|l|}{ Self-Guided Electric Bike Tours } \\
\hline \multicolumn{5}{|l|}{$\begin{array}{l}\text { hire of a state-of-the-art electric bike that can travel at } \\
\text { speeds of } 25 \text { to } 30 \mathrm{~km} / \mathrm{h} \text { on flat ground without pedaling, a } \\
\text { gourmet lunch, } 1 \text { night accommodation in a } 3 \text { Star resort } \\
\text { and an Island map and information }\end{array}$} \\
\hline \multicolumn{5}{|l|}{ Art/Cultural Precinct } \\
\hline $\begin{array}{l}\text { A cultural and sustainable living precinct on Magnetic } \\
\text { Island which provides the opportunity to have a guided art } \\
\text { safari of artist residences and galleries on the island } \$ 30 \text { for }\end{array}$ & & & & Safari-21\% \\
\hline $\begin{array}{l}2 \text { hour tour or to participate in an art/craft workshop } \\
\text { approximately } \$ 45 \text { for } 2 \text { hours and to purchase local arts, } \\
\text { crafts and sustainable products in shops }\end{array}$ & $28 \%$ & $39 \%$ & $29 \%$ & $\begin{array}{c}\text { Workshop- } \\
34 \%\end{array}$ \\
\hline
\end{tabular}

Figures are the percentage of respondents giving a 4-5 rating, all scales were 5 points from 1 not at all to 5 very.

The second step in the survey data analysis was to identify those visitors most interested in the sustainability initiatives and proposed tourism scenarios. Four sustainability market segments were identified. Committed Sustainable Visitors made up 17\% of the sample and were those that scored a 4 or 5 on all the items related to the overall appeal of the four ST products and support for the general sustainability initiatives. Passive Sustainability Supporters made up 35\% of the sample and they scored moderately highly on all the sustainability items. The third segment (15\%) was labeled Neutral/Indifferent as they mostly chose the neutral option. The remaining $33 \%$ of the sample were those respondents who gave mostly negative ratings for the sustainability options. A closer examination of the Committed and Passive sustainability markets indicated that they were very similar in their profiles and together were significantly different to the other two groups on a number of factors. The only significant differences between these two sustainability markets were that 
respondents in the Committed Sustainability group were significantly more likely to say they were willing/able to pay for the ST products, to be staying longer in the region if they were tourists, to rank the opportunity to spend time in natural environments as more important to their visit to MI, and, if they did not visit MI, to report that they did not perceive it as a place that could provide the type of holiday and activities they were interested in. Visitors in Committed and Passive Sustainability segments were more likely than the other two groups to:

- Be female;

- Be first time visitors to the region if they were tourists;

- Rank learning about local culture and history and Indigenous culture, seeing wildlife and selecting environmentally and socially responsible tours and accommodation as more important to their visit MI;

- Use buses for transport on MI;

- Report being busy as a major reason for not visiting MI; and

- To be domestic tourists from the adjacent regions.

Further, the majority of respondents in both these groups (more than $70 \%$ in each group) were either regional residents or tourists who came from surrounding areas.

Overall there was support for the four tourism scenarios and the general MI sustainability initiatives suggesting that the actions could be commercially viable. In addition the strongest support came from visitors who do not have to travel far, who are interested in learning, and who are likely to stay longer both on MI and in the region. All of these are preliminary indicators of sustainability beyond MI. The results also suggested that there were low levels of awareness of the MI sustainability actions and therefore there is potential to increase visitation from markets with a stronger interest in responsible travel and recreation.

\subsection{Outcomes and Future Directions}

The results of the various activities within the funded project provided evidence that tourism had potential value in supporting MI residents' sustainability and QoL aspirations. An action plan was drawn up to incorporate MI stakeholder responses to the action research results as a formal finish to the funded project. The main elements of the action plan are summarized in Table 4. Subsequent projects, funded by various agencies, include the design and installation of interpretive signage, the completion of an underwater snorkel trail, refurbishment of various walking trails and the formal adoption of an educational tourism program including the development of a social marketing professional short course that uses several MI tourism opportunities and locations to highlight aspects of social marketing. Preliminary steps have also been taken towards incorporating various environmental causes, particularly related to marine turtle conservation, into events and tourism experiences. In addition to pursuing the other actions in the plan, there is also a need to further examine the potential tourist markets, evaluate projects that have been completed, and to develop and apply a more detailed pre-implementation sustainability assessment to the tourism scenarios. 
Table 4. Key elements of MI tourism action plan.

\begin{tabular}{ll}
\hline \multicolumn{1}{c}{ Theme } & \multicolumn{1}{c}{ Proposed Actions } \\
\hline Nelly Bay Terminal & $\begin{array}{l}\text { Improve appearance, better use of the space to educate/inform visitors, } \\
\text { have greater resident engagement in consultation for further planning }\end{array}$ \\
\hline $\begin{array}{l}\text { Enhancing Visitor } \\
\text { Experience }\end{array}$ & $\begin{array}{l}\text { Communicate the Solar City story, develop interpretive programs for sustainable } \\
\text { lifestyles, wildlife, and environment, and interpretive signage to walks. }\end{array}$ \\
\hline National Park User Fee & Investigate implementation options for user fee, identify sustainable camping options \\
\hline $\begin{array}{l}\text { Sustainable Transport } \\
\text { Systems }\end{array}$ & $\begin{array}{l}\text { Increase subsidies for residents, extend public transport hours, investigate costs of } \\
\text { electric buses, improve roads, extend foot paths and bicycle paths }\end{array}$ \\
\hline $\begin{array}{l}\text { Revitalisation of Picnic } \\
\text { Bay }\end{array}$ & $\begin{array}{l}\text { Develop as art and culture precinct, research alternative uses of original jetty, } \\
\text { identify and develop events }\end{array}$ \\
\hline Indigenous Tours & Identify guides and potential content, increase capacity of Indigenous guides \\
\hline Protect Key Assets & $\begin{array}{l}\text { Reduce litter and waste, monitor effect of dredging associated with Townsville } \\
\text { port expansion }\end{array}$ \\
\hline Art Tours & Build network of artists, establish a workshop program, find a venue for workshops \\
\hline Event Strategy & Develop a calendar of events, research new event ideas \\
\hline Destination Marketing & $\begin{array}{l}\text { Use Solar City as a marketing tool, link to slow travel, encourage longer stays, } \\
\text { change use of images to reflect aspirations, develop educational tourism }\end{array}$ \\
\hline $\begin{array}{l}\text { Further Understand } \\
\text { Visitors }\end{array}$ & \begin{tabular}{l} 
Regular collection of visitors information, further investigate new/potential markets \\
\hline
\end{tabular}
\end{tabular}

\subsection{Cautionary Notes}

It is important to recognize some of the problems faced during the project. Firstly, the funded project is not sufficient on its own to move towards a new model of sustainability in tourism practice and further work is clearly necessary, although it is not clear where the support for such ongoing work will come from. The project did bring together a number of individuals and organizations and achieved some consensus, but there remains considerable mistrust and unwillingness amongst some MI residents and businesses to engage in the kinds of activities that are needed for greater community or public involvement in tourism governance. The project, especially the tourist and visitor survey, was opposed by some residents as a waste of resources, and there certainly continues to be a group of people reluctant to even discuss tourism. Some of the tourism businesses also felt that any discussion of tourism and sustainability, especially about new tourism options, implied that current activities were not sustainable and they felt the need to defend their existing track record. This particular case is also hampered by the problems of how to best deal with the physical legacy of the Nelly Bay Harbour development, which was not directly considered in this project.

There is also reluctance on the part of government and quasi-government agencies to relinquish control over tourism planning and the formal government funded tourism planning process is still very much a top down externally driven exercise. The lack of community consensus exacerbates this lack of trust in communities from government agencies and this is not an uncommon situation in community development [70]. Changes in state and national governments have also resulted in considerably less government support for community sustainability actions and this wider political context can significantly change the parameters for tourism. Taken together these factors can make the role of the academic facilitators difficult and the prospect of continued engagement in the process is a daunting one. 


\section{Implications and Conclusions}

Dunphy and Benveniste have identified six different ways in which businesses can approach sustainability [71]. The first two are rejection, where the business denies both the issues driving, and the importance of, sustainability, and non-responsiveness, referring to a lack of awareness of sustainability. The second two are compliance and eco-efficiency. Compliant businesses do what is required by regulation and/or pressure from key stakeholders and no more, while eco-efficient businesses go beyond compliance to adopt sustainability actions that can be directly linked to cost savings and efficient production. The fifth approach, called Strategic sustainability, is a logical extension of eco-efficiency which recognizes that sustainability can be used as a competitive strategy and linked to indirect business benefits. In this fifth approach the primary goal is the continued viability and profitability of the business. The final approach is Ideological Commitment or the Sustaining corporation and it is fundamentally different to the previous approaches in that the primary goal is a clear and significant contribution to the well-being of the planet and the quality of life of people in general [72]. Businesses in this approach examine not just the immediate impacts of their own business activities, but address impacts throughout the entire lifecycle of their product or service, consider the value of the product or service to those who consume it and actively work at improving sustainability beyond their business or sector [72].

Current conceptualizations of sustainable tourism can be seen as falling between the eco-efficiency and strategic sustainability approaches. This paper argues that tourism overall needs to move into the Ideological commitment stage and tourism planners, managers and businesses need to strive to become sustaining rather than just sustainable. This paper has outlined a preliminary framework for analyzing tourism that could support such a move. While this is a preliminary framework and more development is needed, the case study demonstrated that it can be used to change the way governments, communities and businesses think about tourism and sustainability.

\section{Acknowledgments}

The authors wish to acknowledge the contributions and support of Sealink Qld, Townsville Enterprise, the Townsville City Council, TOBMI, MICDA, and the businesses and residents of Magnetic Island in the project described in this paper.

\section{Author Contributions}

Each author contributing equally to the development, implementation and analysis of this data presented in this paper and to the writing of the paper itself.

\section{Conflicts of Interest}

The authors declare no conflict of interest. 


\section{References}

1. Hawaiian town of Kailua asks state to stop recommending it as a tourist destination. Available online: http://mobile.news.com.au/travel/travel-updates/hawaiian-town-of-kailua-asks-state-tostop-recommending-it-as-a-tourist-destination/story-e6frfq80-1226760222700 (accessed on 13 November 2013).

2. Cohen, E. The impact of tourism on the physical environment. Ann. Tour. Res. 1978, 5, 215-237.

3. Jafari, J. Research and scholarship: The basis of tourism education. J. Tour. Stud. 1990, 1, 33-41.

4. Macbeth, J. Towards an ethics platform for tourism. Ann. Tour. Res. 2005, 32, 962-984.

5. Hardy, A.; Beeton, R.S.; Pearson, L. Sustainable tourism: An overview of the concept and its position in relation to conceptualisations of tourism. J. Sustain. Tour. 2002, 10, 475-495.

6. Saarinen, J. Traditions of sustainability in tourism studies. Ann. Tour. Res. 2006, 33, 1121-1140.

7. Jamal, T.; Camargo, B.A.; Wilson, E. Critical omissions and new directions for sustainable tourism: A situated macro-micro approach. Sustainability 2013, 5, 4594-4613.

8. Moscardo, G. Sustainable tourism innovation: Challenging basic assumptions. Tour. Hospit. Res. 2008, 8, 4-13.

9. Moscardo, G. Tourism and quality of life: Towards a more critical approach. Tour. Hospit. Res. 2009, 9, 159-170.

10. McCool, S.F. Mountains and tourism: Meeting the challenges of sustainability in a messy world. In Celebrating Mountains, Proceedings of an International Year of Mountain Conference, Jindabyne, Australia, 27 November 2002; pp. 311-318.

11. Moscardo, G. Exploring social representations of tourism planning: Issues for governance. J. Sustain. Tour. 2011, 19, 423-436.

12. Getz, D. Models in tourism planning: Towards integration of theory and practice. Tour. Manag. 1986, 7, 21-32.

13. Butler, R.W. Problems and issues of integrating tourism development. In Contemporary Issues in Tourism Development; Pearce, D.G., Butler, R.W., Eds.; Routledge: London, UK, 1999; pp. 65-80.

14. Wall, G. Is ecotourism sustainable? Environ. Manag. 1997, 21, 483-491.

15. Moscardo, G. Challenges for tourism development on Australia's Great Barrier Reef coast. In Coastal Tourism Development_Planning and Management Issues; Dowling, R., Pforr, C., Eds.; Cognizant Communications: New York, NY, USA, 2009; pp. 252-264.

16. Jafari, J. Bridging out, nesting afield: Powering a new platform. J. Tour. Stud. 2005, 16, 1-5.

17. Jovicic, D.Z. Key issues in the implementation of sustainable tourism. Curr. Issues Tour. 2013, doi:10.1080/13683500.2013.797386.

18. Holden, A. The environment-tourism nexus-Influence of market ethics. Ann. Tour. Res. 2009, $36,373-389$.

19. Leslie, D. Introduction. In Responsible Tourism: Concepts, Theory and Practice; Leslie, D., Ed.; CABI: Wallingford, UK, 2012; pp. 1-16.

20. Glossary of statistical terms. Available online: http://stats.oecd.org/glossary/detail.asp?ID=2218 (accessed on 1 December 2013). 
21. Moscardo, G. Building social capital to enhance the Quality-of-life of destination residents. In Handbook of Tourism and Quality-of-Life Research; Uysal, M., Perdue, R., Sirgy, M.J., Eds.; Springer: New York, NY, USA, 2012; pp. 403-422.

22. Costanza, R.; Fisher, B.; Ali, S.; Beer, C.; Bond, L.; Boumans, R.; Danigelis, N.L.; Dickinson, J.; Elliott, C.; Farley, J.; et al. Quality of life: An approach integrating opportunities, human needs, and subjective well-being. Ecol. Econ. 2007, 61, 267-276.

23. Malkina-Pykh, I.G.; Pykh, Y.A. Quality-of-life indicators at different scales: Theoretical background. Ecol. Indicat. 2008, 8, 854-862.

24. Lehtonen, M. The environmental-social interface of sustainable development: Capabilities, social capital, institutions. Ecol. Econ. 2004, 49, 199-214.

25. Vermuri, A.W.; Costanza, R. The role of human, social, built and natural capital in explaining life satisfaction at the country level: Toward a national well-being index. Ecol. Econ. 2006, 58, 119-133.

26. Moscardo, G.; Lamberton, G.; Wells, G.; Fallon, W.; Lawn, P.; Rowe, A.; Humphrey, J.; Wiesner, R.; Pettitt, B.; Clifton, D.; et al. Sustainability in Australian Business: Principles and Practice; Wiley: Brisbane, Australia, 2013.

27. Moscardo, G.; Konovalov, E.; Murphy, L.; McGehee, N. Mobilities, community well-being and sustainable tourism. J. Sustain. Tour. 2013, 21, 532-556.

28. Macbeth, J.; Carson, K.; Northcote, J. Social capital, tourism and regional development: SPCC as a basis for innovation and sustainability. Curr. Issues Tour. 2004, 7, 502-522.

29. McGehee, N.; Lee, S.; O’Bannon, T.; Perdue, R. Tourism-related social capital and its relationships with other forms of capital: An Exploratory study. J. Trav. Res. 2010, 49, 486-500.

30. Andereck, K.; Nyuapane, G. Exploring the nature of tourism and quality of life perceptions amongst residents. J. Trav. Res. 2010, 50, 248-260.

31. Scott, D. Why sustainable tourism must address climate change. J. Sustain. Tour.2011, 19, 17-34.

32. Lansing, P.; de Vries, P. Sustainable tourism: Ethical alternative or marketing ploy? J. Bus. Ethics 2007, 72, 77-85.

33. Hall, C.M. Policy learning and policy failure in sustainable tourism governance: From first- and second-order to third-order change? J. Sustain. Tour. 2011, 19, 649-671.

34. Ruhanen, L. Strategic planning for local tourism destinations: An analysis of tourism plans. Tour. Hospit. Plann. Dev. 2004, 1, 239-253.

35. Ko, T.G. Development of a tourism sustainability assessment procedure: A conceptual approach. Tour. Manag. 2005, 26, 431-445.

36. Garcia-Rosell, J.; Makinen, J. An integrative framework for sustainability evaluation in tourism: Applying the framework to tourism product development in Finnish Lapland. J. Sustain. Tour. 2013, 21, 396-416.

37. Tao, T.C.H.; Wall, G. Tourism as a sustainable livelihood strategy. Tour. Manag. 2009, 30, 90-98.

38. Truong, V.D.; Hall, C.M. Social marketing and tourism: What is the evidence? Soc. Market. $Q$. 2013, 19, 110-135.

39. Marzuki, A.; Hay, I. Towards a public participation framework in tourism planning. Tour. Plann. Dev. 2013, doi:10.1080/21568316.2013.804432. 
40. Moscardo, G. Community capacity building-An emerging challenge for tourism development. In Building Community Capacity for Tourism Development; Moscardo, G., Ed.; CABI: Wallingford, UK, 2008; pp. 1-15.

41. Botes, L.; van Rensburg, D. Community participation in development: Nine plagues and twelve commandments. Commun. Dev. J. 2000, 35, 41-68.

42. Feighery, W.G. Consulting ethics. Ann. Tour. Res. 2011, 38, 1031-1050.

43. Moriarty, J.P. Theorising scenario analysis to improve future perspective planning in tourism. J. Sustain. Tour. 2012, 20, 779-800.

44. Coria, J.; Calfucura, E. Ecotourism and the development of indigenous communities: The good, the bad, and the ugly. Ecol. Econ. 2012, 73, 47-56.

45. Department of National Parks, Recreation, Sport and Racing. About Magnetic Island. Available online: http://www.nprsr.qld.gov.au/parks/magnetic-island/about.html (accessed on 11 November 2013).

46. Australian Bureau of Statistics. National regional profile: Magnetic Island. Available Online: http://www.abs.gov.au/ausstats/abs@nrp.nsf/781eb7868cee03e9ca2571800082bece/2a3e7368b29 b7557ca2577d50011bdaa!OpenDocument (accessed on 11 November 2013).

47. Pure Magnetic. Island History. Available online: http://www.puremagnetic.com/page.asp?CID= magnetic-island-history (accessed on 11 November 2013).

48. Australian Heritage. Magnetic Island. Available online: http://www.heritageaustralia.com.au/ search.php?state=QLD\&region=93\&view=1232 (accessed on 11 November 2013).

49. Harrington, J.T. 'Being here': Heritage, Belonging and Place Making. Ph.D. Thesis, James Cook University, Townsville, Australia, 2004.

50. Dickie, P. Nelly Bay. Available online: http://www.rag.org.au/phildickiestories/Walkden.htm (accessed on 12 November 2013).

51. Heywood, P. Social justice and planning for the public interest. Urban Pol. Res. 1990, 8, 60-68.

52. Great Barrier Reef Marine Park Authority. Nelly Bay Harbour Development. Available online: http://www.gbrmpa.gov.au/outlook-for-the-reef/great-barrier-reef-outlook-report/outlook-online? sq_content_src=\%2BdXJsPWh0dHAlM0ElMkYlMkZ3d3ctcmMuZ2JybXBhLmdvdi5hdSUyRm NvcnBfc210ZSUyRm1hbmFnZW11bnQ1MkZlYW01MkZlaWElMkZuZWxseV9iYXkmYWxsPT E\%3D (accessed on 13 November 2013).

53. Valentine, P. Community response to tourism proposals on Magnetic Island. Urban Pol. Res. 1989, 7, 83-85.

54. Moyle, B.B.; Croy, G.; Weiler, B. Community perceptions of tourism: Bruny and Magnetic Islands, Australia. Asia Pac. J. Tour. Res. 2010, 15, 353-366.

55. Asher, C.; Roe, D.; Goodwin, H. Pro-Poor Tourism Strategies: Making Tourism Work for the Poor; Overseas Development Institute: Nottingham, UK, 2001.

56. Blackstock, K. A critical look at community based tourism. Commun. Dev. J. 2005, 40, 39-49.

57. Dredge, D. Place change and tourism development conflict: Evaluating public interest. Tour. Manag. 2010, 31, 104-112.

58. Holladay, P.J.; Powell, R.B. Resident perceptions of social-ecological resilience and the sustainability of community-based tourism development in the Commonwealth of Dominica. J. Sustain. Tour. 2013, doi:10.1080/09669582.2013.776059. 
59. Lee, T.J.; Riley, M.; Hampton, M.P. Conflict and progress: Tourism development in Korea. Ann. Tour. Res. 2010, 37, 355-376.

60. Park, D.B.; Lee, K.W.; Choi, H.S.; Yoon, Y. Factors influencing social capital in rural tourism communities in South Korea. Tour. Manag. 2012, 33, 1511-1520.

61. Townsville City Council. Townsville tourism industry. Available online: http://www.townsville. qld.gov.au/townsville/tourism/Pages/industry.aspx (accessed on 16 November 2013).

62. Tourism Queensland. Destination Management Plan for Tourism in Townsville North Queensland 2007-2010; Tourism Queensland: Brisbane, Australia, 2007.

63. Tourism Queensland. Townsville North Queensland Tourism Opportunity Plan 2009-2019; Tourism Queensland: Brisbane, Australia, 2009.

64. Townsville Solar City. Magnetic Island Solar Suburb. Available online: http://www.townsvillesolarcity.com.au/Project Overview/tabid/64/default.aspx (accessed on 16 November 2013).

65. Bruce, A.; Heslop, S.; Macgill, I.; Watt, M. Magnetic Island and Townsville Solar City; Australian Renewable Energy Agency: Canberra, Australia, 2013.

66. Isaac, J. Smart living on Magnetic Island. Ecos 2009, 148, 9.

67. Ergon Energy. Magnetic Island's successful Solar City project wraps up. Available online: http://www.ergon.com.au/about-us/news-room/media-releases/regions/northern/magneticislands-successful-solar-city-project-wraps-up (accessed on 16 November 2013).

68. Citiwater Townsville. Magnetic Island Water Recycling; Citiwater: Townsville, Australia, 2002.

69. Tourism Queensland. Sustainable Regions for Queensland_Magnetic Island; Tourism Queensland: Brisbane, Australia, 2009.

70. Eversole, R. Managing the pitfalls of participatory development: Some insight from Australia. World Dev. 2003, 31, 781-795.

71. Dunphy, D.; Benveniste, J. An introduction to the sustainable corporation. In Sustainability: The Corporate Challenge of the 21st Century; Dunphy, D., Benveniste, J., Griffiths, A., Sutton, P., Eds.; Allen \& Unwin: Sydney, Australia, 2000; pp. 3-18.

72. Benn, S.; Dunphy, D.; Griffiths, A. Enabling change for corporate sustainability: An integrated perspective. Australas. J. Environ. Manag. 2006, 13, 156-165.

(C) 2014 by the authors; licensee MDPI, Basel, Switzerland. This article is an open access article distributed under the terms and conditions of the Creative Commons Attribution license (http://creativecommons.org/licenses/by/3.0/). 